\title{
Identify Potential Lock Treatment Options to Prevent Movement of Aquatic Invasive Species through the Chicago Area Waterway System (CAWS)
}

Open-File Report 2016-1001 



\section{Identify Potential Lock Treatment Options to Prevent Movement of Aquatic Invasive Species through the Chicago Area Waterway System (CAWS)}

By Terrance D. Hubert, Michael Boogaard, and Kim T. Fredricks

Open-File Report 2016-1001

U.S. Department of the Interior

U.S. Geological Survey 


\title{
U.S. Department of the Interior SALLY JEWELL, Secretary
}

\section{U.S. Geological Survey Suzette M. Kimball, Director}

\author{
U.S. Geological Survey, Reston, Virginia: 2016
}

For more information on the USGS—-the Federal source for science about the Earth, its natural and living resources, natural hazards, and the environment-visit http://www.usgs.gov or call 1-888-ASK-USGS (1-888-275-8747)

For an overview of USGS information products, including maps, imagery, and publications, visit http://www.usgs.gov/pubprod

To order this and other USGS information products, visit http://store.usgs.gov

Any use of trade, firm, or product names is for descriptive purposes only and does not imply endorsement by the U.S. Government.

Although this information product, for the most part, is in the public domain, it also may contain copyrighted materials as noted in the text. Permission to reproduce copyrighted items must be secured from the copyright owner.

Suggested citation:

Hubert, T.D., Boogaard, M.A., and Fredricks, K.T., 2016, Identify potential lock treatment options to prevent movement of aquatic invasive species through the Chicago Area Waterway System (CAWS): U.S. Geological Survey Open-File Report 2016-1001, 16 p., http://dx.doi.org/10.3133/ofr20161001. 


\section{Contents}

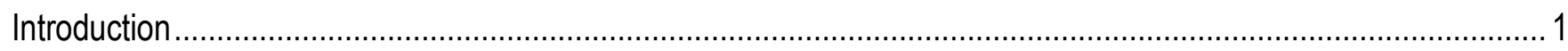

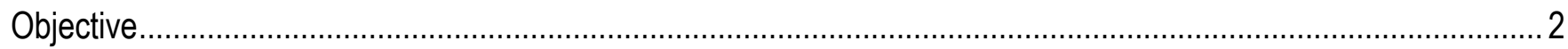

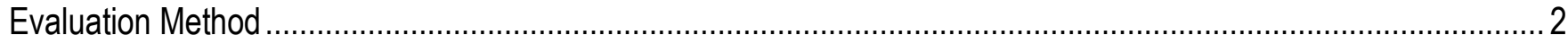

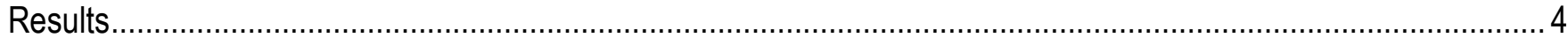

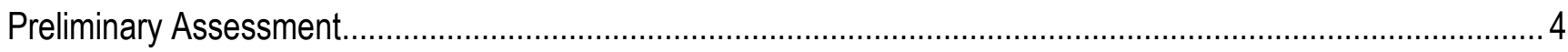

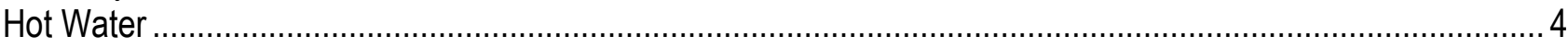

Nitrogen and Carbon Dioxide .................................................................................................... 4

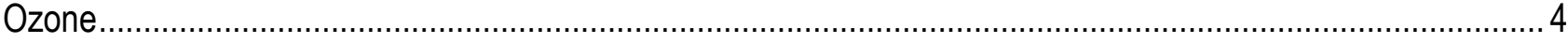

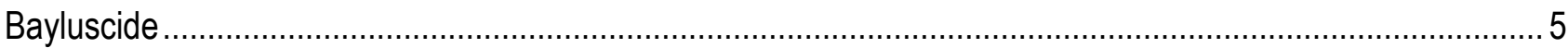

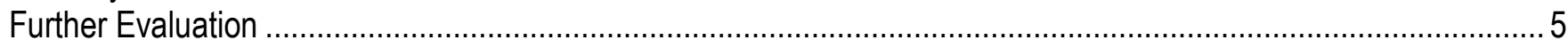

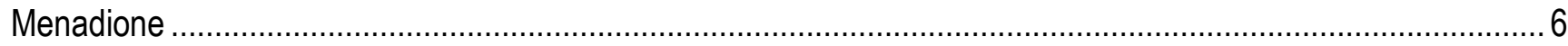

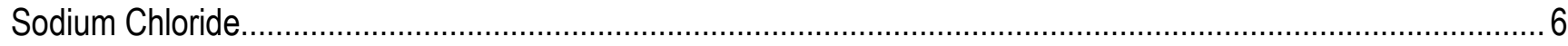

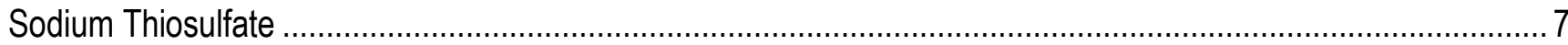

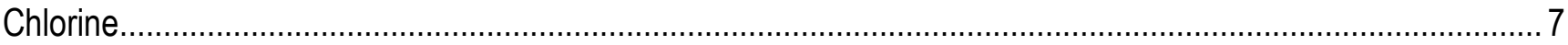

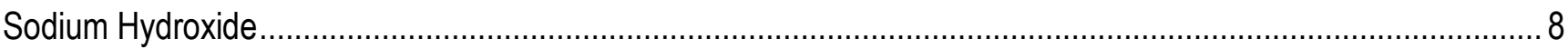

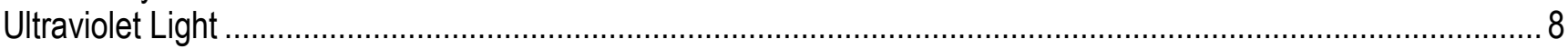

Control Method Effects on Taxonomic Groups..................................................................................... 8

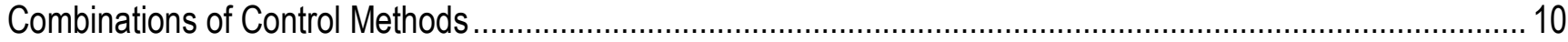

Potential Control of Scud (Gammarus spp.)....................................................................................... 14

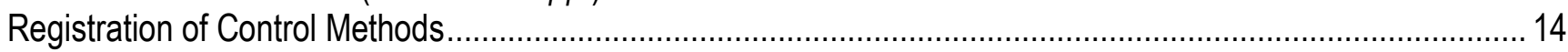

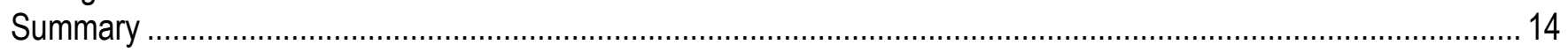

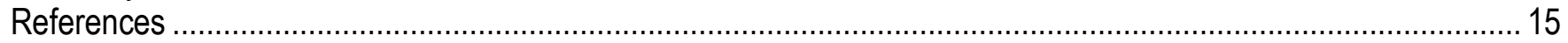

\section{Figures}

Figure 1. Schematic of barge moving through a lock chamber.

Figure 2. Solubility of sodium chloride at various temperatures. (Data from the CRC Handbook of Chemistry and Physics, 90th edition 2009-10, David Lide, ed., p. 830) ………............................................................ 7

\section{Tables}

Table 1. Evaluation of potential lock treatment options. Options were scored from 1 to 5 with 1 being a low score and 5 being a high score. Options are ranked based on total score. A score highlighted in red text indicates that insufficient data were available to fully evaluate the option in that category.

Table 2. Re-evaluation of the top treatment options and additional options requested by The Nature Conservancy. Impacts to vessels and impacts to lock structure were separated into individual categories. Options were ranked by total score as in the initial evaluation. A score highlighted in red text indicates that insufficient data were available to fully evaluate the option in that category......

Table 3. Toxicity of the various chemical treatment options to taxa of concern. Toxicity is ranked from 1 to 5 based on LC50 data where available.

Table 4. Control method compatibility table. Each binary combination of control options was assessed for compatibility and given a score of 0 to 3 , with 0 being not compatible and 3 being compatible and likely to enhance toxicity.

Table 5. Summary of toxicity data relevant to taxa of concern for lock-treatment control methods. 


\section{Conversion Factors}

International System of Units to Inch/Pound

\begin{tabular}{|c|c|c|}
\hline Multiply & By & To obtain \\
\hline \multicolumn{3}{|c|}{ Length } \\
\hline centimeter $(\mathrm{cm})$ & 0.3937 & inch (in.) \\
\hline millimeter (mm) & 0.03937 & inch (in.) \\
\hline \multicolumn{3}{|c|}{ Volume } \\
\hline liter (L) & 33.814 & ounce, fluid (fl. oz) \\
\hline liter (L) & 2.11338 & pint (pt) \\
\hline liter (L) & 1.05669 & quart (qt) \\
\hline liter (L) & 0.264172 & gallon (gal) \\
\hline cubic meter $\left(\mathrm{m}^{3}\right)$ & 264.172 & gallon (gal) \\
\hline \multicolumn{3}{|c|}{ Flow rate } \\
\hline centimeters per second $(\mathrm{cm} / \mathrm{sec})$ & 0.0328 & foot per second (ft/sec) \\
\hline \multicolumn{3}{|c|}{ Mass } \\
\hline $\begin{array}{l}\text { milligram (mg) } \\
\text { (m) }\end{array}$ & $3.5274 \times 10^{-5}$ & ounce, avoirdupois (oz) \\
\hline kilogram (kg) & 2.20462 & pound, avoirdupois (lb) \\
\hline
\end{tabular}

Temperature in degrees Celsius $\left({ }^{\circ} \mathrm{C}\right)$ may be converted to degrees Fahrenheit $\left({ }^{\circ} \mathrm{F}\right)$ as ${ }^{\circ} \mathrm{F}=\left(1.8 \times{ }^{\circ} \mathrm{C}\right)+32$.

\section{Supplemental Information}

Concentrations of chemical constituents in water are given in milligrams per liter (mg/L).

\section{Abbreviations}

2,4-D 2,4-Dichlorophenoxyacetic acid

AIS aquatic invasive species

CAWS Chicago Area Waterways System

EC50 half maximal effective concentration

FIFRA Federal Insecticide, Fungicide, and Rodenticide Act

GLMRIS Great Lakes Mississippi River Interbasin Study

LC50 lethal concentration to 50 percent of population

MAK Maximal Arbeitsstoff Konzentration (Maximal Material Concentration)

PAN Pesticide Action Network

TFM 3-trifluoromethyl-4-nitrophenol

USACE United States Army Corps of Engineers

EPA United States Environmental Protection Agency

UV ultraviolet 


\title{
Identify Potential Lock Treatment Options to Prevent Movement of Aquatic Invasive Species through the Chicago Areas Waterway System (CAWS)
}

\author{
By Terrance D. Hubert, Michael A. Boogaard, and Kim T. Fredricks
}

\section{Introduction}

Many interest groups desire to stop the two-way movement of all Aquatic Invasive Species (AIS) through Chicago Area Waterways System (CAWS) from Lake Michigan, as well as from the Illinois River. One option under consideration is to develop a lock treatment process that stops AIS from entering (and moving through) the CAWS, while at the same time not unduly impeding the movement of barges and other boat traffic between Lake Michigan and the Mississippi River.

Solutions to significantly reduce the threat of AIS movement between the Great LakesMississippi River Basins, proposed in the Great Lakes Mississippi River Interbasin Study (GLMRIS) and the "Restoring the Natural Divide" report, required more than 20 years to implement and provided no process for improving control in the interim period. Lock treatment is one option that potentially could be implemented in a relatively short time. Initial discussions have favored the idea of establishing measures centered around the locks at the upper (O’Brien) and lower (Brandon Road) end of the CAWS so these act as one-way barriers that together would prevent movement of organisms into and through the canal system.

To better illustrate the concept, the Brandon Road Lock could be managed in a manner that would prevent upstream movement of AIS. Boats and barges moving upstream would pass through an engineered channel with a combination of deterrent measures to prevent the number of fish and other mobile taxa entering Brandon Road Lock with the vessels. Once the vessels enter the lock at low water and the lock is closed, the held water would be treated to kill all AIS to prevent their movement upstream (fig. 1). After treatment, the lock will be detoxified and flooded with CAWS water to achieve the necessary lift. Once at the level of the CAWS, the gates are opened and the vessels released into the CAWS for passage upstream.

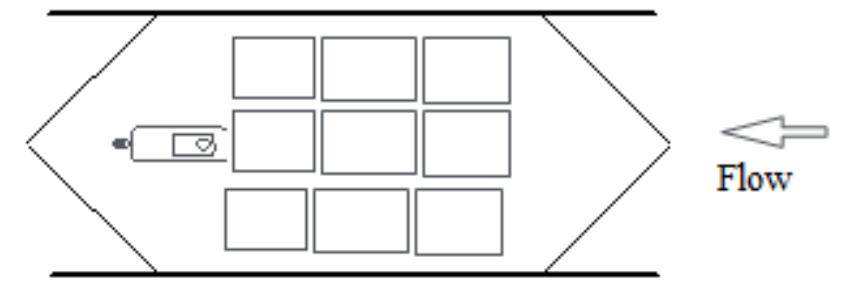

Figure 1. Schematic of barge moving through a lock chamber. 
Boats and barges moving downstream through the lock would enter the lock at high water (CAWS level) and then the lock is closed. The held water volume and the boats and barges in the lock are from the CAWS, and no treatment would be necessary assuming a similar one-way lock is operating in the Upper CAWS to prevent passage of unwanted organisms into the CAWS. Therefore, all lock water could be released with the vessels into the Mississippi River Basin.

\section{Objective}

To evaluate options for treating vessels for control of aquatic invasive species during lock operations with an emphasis on chemical methods.

\section{Evaluation Method}

A list of potential lock-treatment options, with a focus on chemicals, was generated using the Integrated Management Techniques to Control Nonnative Fishes completion report prepared for the Bureau of Reclamation (Dawson and Kolar, 2003) and the Inventory of Available Controls for Aquatic Nuisance Species of Concern Chicago Area Waterway System (GLMRIS, 2012). Additional chemicals were added to the list based on information presented in a report by Moy and others (2011). Once the list was developed, a brief literature search on each of the potential treatment options was conducted to gather information related to advantages and disadvantages of using the chemical in the lock system. The literature was summarized and distributed to three reviewers who used it to develop rankings for each of the potential treatment chemicals. The nine criteria described in the project proposal were used to evaluate and rank each of the options.

In this evaluation, 1 was a poor score and 5 was a superior score. The scores for each of the nine criteria were then summed to provide an overall score, which was used to rank the options highest (best option) to lowest (poorest option). The scores are summarized in table 1 . A perfect score would be 45, and the lowest possible score would be 9 . The criteria were considered of equal importance, so no weighting was applied. Three individuals with experience in fish-control methods individually ranked the options. The group then reviewed individual criteria scores of each chemical and arrived at a composite score for each criterion. The composite scores and ranking are listed in the table provided. It is important to note that the scoring system was imperfect in that in some instances, certain gaps in information existed about the chemical in the criterion. If this was the case, and it was not possible to compare the chemical to a similar chemical, then the compound was given a score of " 3 " and the number highlighted in red to distinguish it from scores in which the rating had a higher level of confidence. 
Table 1. Evaluation of potential lock treatment options. Options were scored from 1 to 5 with 1 being a low score and 5 being a high score. Options are ranked based on total score. A score highlighted in red text indicates that insufficient data were available to fully evaluate the option in that category.

$\left[{ }^{\circ} \mathrm{C}\right.$, degrees Celsius. Criterion Ranking (1-5):1, Suitability/viability for large-scale application treatments or recirculating treatments $(1=$ lowest suitability/viability); 2 , Rapid lethality/contact time $(1=$ highest contact time required); 3 , Lethal to full range of taxa and life stages ( 1 = lethal to lowest range of taxa); 4 , Impacts to vessels and lock structure (1 = highest impact to vessels and lock); 5 , Human Safety ( 1 = highest impact to human safety); 6, Ease of detoxification ( 1 = least easy to detoxify); 7, Environmental safety $(1=$ highest impact to environment); 8, Likelihood of registration ( 1 = least likely to be registered); 9 , Availability/cost $(1=$ least available/most costly)]

\begin{tabular}{|c|c|c|c|c|c|c|c|c|c|c|}
\hline \multicolumn{11}{|c|}{ Criterion number and score } \\
\hline Option & 1 & 2 & 3 & 4 & 5 & 6 & 7 & 8 & 9 & Total score \\
\hline $43^{\circ} \mathrm{C}$ water & 4 & 5 & 5 & 4 & 3 & 5 & 5 & 5 & 4 & 40 \\
\hline Nitrogen & 4 & 3 & 3 & 5 & 5 & 5 & 4 & 5 & 4 & 38 \\
\hline Carbon dioxide & 4 & 3 & 3 & 4 & 5 & 5 & 4 & 5 & 4 & 37 \\
\hline Ozone & 3 & 5 & 4 & 4 & 4 & 5 & 5 & 4 & 3 & 37 \\
\hline Bayluscide & 5 & 4 & 3 & 5 & 5 & 3 & 3 & 3 & 4 & 35 \\
\hline Menadione & 4 & 3 & 4 & 5 & 3 & 3 & 3 & 4 & 4 & 33 \\
\hline Rotenone & 5 & 3 & 3 & 5 & 3 & 3 & 3 & 3 & 4 & 32 \\
\hline Hydrogen peroxide & 4 & 3 & 3 & 2 & 3 & 5 & 4 & 4 & 4 & 32 \\
\hline Ultraviolet light & 1 & 2 & 2 & 5 & 4 & 5 & 5 & 4 & 3 & 31 \\
\hline $\begin{array}{l}\text { 3-trifluoromethyl-4- } \\
\text { nitrophenol }\end{array}$ & 5 & 2 & 3 & 5 & 3 & 3 & 3 & 3 & 4 & 31 \\
\hline Potassium permanganate & 4 & 3 & 2 & 3 & 3 & 3 & 3 & 4 & 5 & 30 \\
\hline Sodium chloride & 4 & 1 & 3 & 1 & 4 & 4 & 3 & 4 & 5 & 29 \\
\hline Imazapyr & 3 & 1 & 1 & 5 & 4 & 3 & 3 & 4 & 5 & 29 \\
\hline Chlorine & 3 & 5 & 5 & 1 & 2 & 3 & 2 & 2 & 5 & 28 \\
\hline Squoxin & 4 & 2 & 1 & 5 & 3 & 3 & 4 & 4 & 2 & 28 \\
\hline Glyphosate & 4 & 1 & 1 & 5 & 4 & 3 & 2 & 3 & 5 & 28 \\
\hline Sodium thiosulfate & 3 & 1 & 4 & 3 & 3 & 3 & 3 & 3 & 4 & 27 \\
\hline Sodium sulfite & 3 & 2 & 2 & 3 & 3 & 4 & 3 & 3 & 4 & 27 \\
\hline Euphorbia extract & 3 & 4 & 1 & 5 & 3 & 3 & 4 & 2 & 2 & 27 \\
\hline Diquat & 3 & 1 & 1 & 5 & 3 & 3 & 2 & 4 & 5 & 27 \\
\hline Triclopyr-TEA & 3 & 1 & 1 & 5 & 3 & 3 & 2 & 4 & 5 & 27 \\
\hline Copper compounds & 3 & 1 & 1 & 5 & 3 & 3 & 2 & 4 & 4 & 26 \\
\hline Calcium carbonate & 3 & 2 & 3 & 2 & 3 & 2 & 3 & 3 & 4 & 25 \\
\hline Fluridone & 3 & 1 & 1 & 4 & 4 & 3 & 3 & 4 & 1 & 24 \\
\hline Endothall & 3 & 1 & 1 & 5 & 1 & 4 & 3 & 3 & 3 & 24 \\
\hline Antimycin & 3 & 1 & 2 & 5 & 2 & 3 & 3 & 3 & 1 & 23 \\
\hline $\begin{array}{l}\text { 2,4-Dichlorophenoxyacetic } \\
\text { acid }\end{array}$ & 3 & 1 & 1 & 5 & 3 & 3 & 1 & 1 & 5 & 23 \\
\hline Granular algaecide & 3 & 1 & 1 & 5 & 4 & 4 & 3 & 1 & 1 & 23 \\
\hline
\end{tabular}




\section{Results}

\section{Preliminary Assessment}

The top five scoring treatment options were hot water, three gases (nitrogen, carbon dioxide, and ozone), and bayluscide.

\section{Hot Water}

As a result of our scoring process, hot water at approximately $43-49^{\circ} \mathrm{C}$ provided the best combination of lethality, environmental and human safety, efficacy, and cost effectiveness for treating commercial and recreational vessels during a lock through process. Water of this temperature can kill plant or animal life in 10 to 20 minutes (Beyer and others, 2011). The primary environmental concern identified would be that release of water at this temperature may cause thermal disruption of the ecosystem immediately below the treatment area. Impacts can be mitigated by cycling the high temperature water into and out of the lock chamber. The primarily human health concern identified would be water at this temperature could cause burns depending on length of exposure. Registration of this option with the U.S. Environmental Protection Agency (EPA), if required, may be accomplished with minimal difficulty. Water is, of course, readily available, and the significant cost of use will be in heating and maintaining the required volumes at the high temperature necessary to be effective. This expense could be minimized if treatment locations were located next to power plants to take advantage of waste heated water.

\section{Nitrogen and Carbon Dioxide}

These two gases are addressed together because their scores were similar in each criterion. Neither is rapidly lethal, but to some degree lethality and exposure time would be concentration dependent. Also they are not toxic to all taxa, particularly to plants. Both of these gases are relatively economical to use and readily available. Impacts to vessels and the lock structure are possible as carbonic acid formation may have an impact. This is being investigated by the U.S. Army Corps of Engineers (USACE). They do not require detoxification because they are common gases found in air and water, and consequently no impacts to humans or animals are expected. Impacts to nontarget aquatic species at the concentrations likely needed for complete lethality of invasive species would need to be studied. Registration may be accomplished with minimal difficulty.

\section{Ozone}

Ozone is rapidly lethal and toxic to many, but not all, of the taxa of concern. It impacts the lock structure as it is corrosive to certain types of cement and steel, and may impact any sealant materials. Ozone is a lung irritant, so personal protective equipment might be necessary for persons engaged in this type of treatment depending on exposure concentrations. A potential concern is that if significant off-gassing occurs, persons on the vessel being treated may be at risk. The space surrounding the vessel, because of the depth of the lock chamber, would be considered a confined space, which introduces specific restrictions. Minimal effect on the environment is expected.

High organic matter in the water would reduce the effectiveness; however, this might be mitigated by replacement of the lock-chamber water prior to treatment. The material is suitable for large-scale use, but the cost of equipment to generate sufficient quantities for repetitive treatments could 
be a limiting factor. Ozone may require similar regulatory efforts as hot water, although it is possible that if the material is generated on-site, no regulation under the Federal Insecticide, Fungicide, and Rodenticide Act (FIFRA) would be needed.

\section{Bayluscide}

Bayluscide is the only synthetic pesticide to rank in the top 5 options. It is used for sea lamprey control in the Great Lakes and could be adapted to these types of treatments. It is unlikely to damage lock structure and is essentially non-toxic to humans. Registration for this type of use could present a challenge (see discussion below). The material is relatively inexpensive and is produced in large quantities by the Bayer Corporation, so it may be readily available.

\section{Further Evaluation}

Following the preliminary assessment, emphasis was placed on the categories of contact time and lethality to a range of taxa. Under this consideration, the top five chemicals are $43{ }^{\circ} \mathrm{C}$ water, chlorine, ozone, menadione, and sodium thiosulfate (table 2). These chemicals were considered further, along with sodium chloride, which is used in control of organisms in ballast water; sodium hydroxide, which is used in closed water applications to clean pipes; and ultraviolet (UV) light.

Table 2. Re-evaluation of the top treatment options and additional options requested by The Nature Conservancy. Impacts to vessels and impacts to lock structure were separated into individual categories. Options were ranked by total score as in the initial evaluation. A score highlighted in red text indicates that insufficient data were available to fully evaluate the option in that category.

$\left[{ }^{\circ} \mathrm{C}\right.$, degrees Celsius]

\begin{tabular}{|c|c|c|c|c|c|c|c|c|c|c|c|}
\hline \multicolumn{12}{|c|}{ Criterion number and score } \\
\hline Option & 1 & 2 & 3 & 4 & 5 & 6 & 7 & 8 & 9 & 10 & Total score \\
\hline $43^{\circ} \mathrm{C}$ water & 4 & 5 & 5 & 4 & 4 & 3 & 5 & 5 & 5 & 4 & 44 \\
\hline Ozone & 3 & 5 & 4 & 3 & 3 & 4 & 5 & 5 & 4 & 3 & 39 \\
\hline Menadione & 4 & 3 & 4 & 5 & 5 & 3 & 3 & 3 & 4 & 4 & 38 \\
\hline Ultraviolet light & 1 & 2 & 2 & 5 & 5 & 4 & 5 & 5 & 4 & 3 & 36 \\
\hline Sodium chloride & 4 & 1 & 3 & 3 & 1 & 4 & 4 & 3 & 4 & 5 & 32 \\
\hline Sodium thiosulfate & 3 & 1 & 4 & 4 & 3 & 3 & 3 & 3 & 3 & 4 & 31 \\
\hline Chlorine & 3 & 5 & 5 & 3 & 1 & 2 & 3 & 2 & 2 & 5 & 31 \\
\hline Sodium hydroxide & 4 & 1 & 1 & 3 & 1 & 2 & 1 & 2 & 2 & 2 & 19 \\
\hline
\end{tabular}




\section{Menadione}

(SeaKleen ${ }^{\circledR}$ ) was developed for ballast-water treatment. However, the manufacturer has not registered the product, apparently due to concerns over toxicity at the time of discharge. The active ingredient in SeaKleen ${ }^{\circledR}$ is menadione (vitamin K3), which would have minimal human health risks. Menadione is not registered with the EPA so testing would be required for the expected use pattern. It was shown to be toxic to a wide variety of non-indigenous aquatic species, including blue-green algae. Most toxicity tests reviewed were $24 \mathrm{~h}$ or longer as it was designed for ballast-water treatment, and greater than 98 percent mortality was achieved for most zooplankton at 1 milligram per liter $(\mathrm{mg} / \mathrm{L})$ or higher over 24 hours (Wright and others, 2007). Results for phytoplankton were similar, with inactivation over 24 hours at $1 \mathrm{mg} / \mathrm{L}$ (Wright and others, 2007). Larval fish and brine shrimp also showed 100 percent mortality with exposure to $1.6 \mathrm{mg} / \mathrm{L}$ SeaKleen ${ }^{\circledR}$ (Wright and others, 2009). From a study on juglone, a structurally related compound, we were able to project a 30 minute LC50 of about 34x more than the 24 hour LC50 (Marking, 1970). SeaKleen ${ }^{\circledR}$ did undergo photodegradation and would likely disappear from treated water within several hours. This should minimize non-target effects. More studies need to be conducted to determine a concentration that would achieve a 100 percent kill in 30 minutes, and additional studies are likely needed to determine environmental and ecological impacts of the proposed concentrations.

\section{Sodium Chloride}

Based on available data, the use of sodium chloride would present some challenges under the treatment scenario proposed. Available data indicate it would take a substantial amount of sodium chloride to cause lethality in a short time (30 minutes or less). For example, data for grass carp-a species related to silver carp and bighead carp-indicate that the approximate concentration needed to cause lethality to fry in 30 minutes is $227,000 \mathrm{mg} / \mathrm{L}$ (table 5). If we estimate a treatment volume of seven million gallons, a total of $6.01 \times 10^{9}$ grams (g) or 6,624 tons of sodium chloride would be necessary. We emphasize that this is for a 30-minute contact time and for small fish, not adults. Additionally, the concentrations of sodium chloride that might be required for rapid lethality may not be achievable. The solubility limit of sodium chloride is largely unaffected by temperature and is approximately 36 percent by weight (fig. 2). Concentrations exceeding 36 percent will form a biphasic mixture between a saturated solution of sodium chloride and sodium chloride solid. Additional testing is needed to establish the required concentration for lethality in 30 minutes or less, and determine if it is of practical utility. 


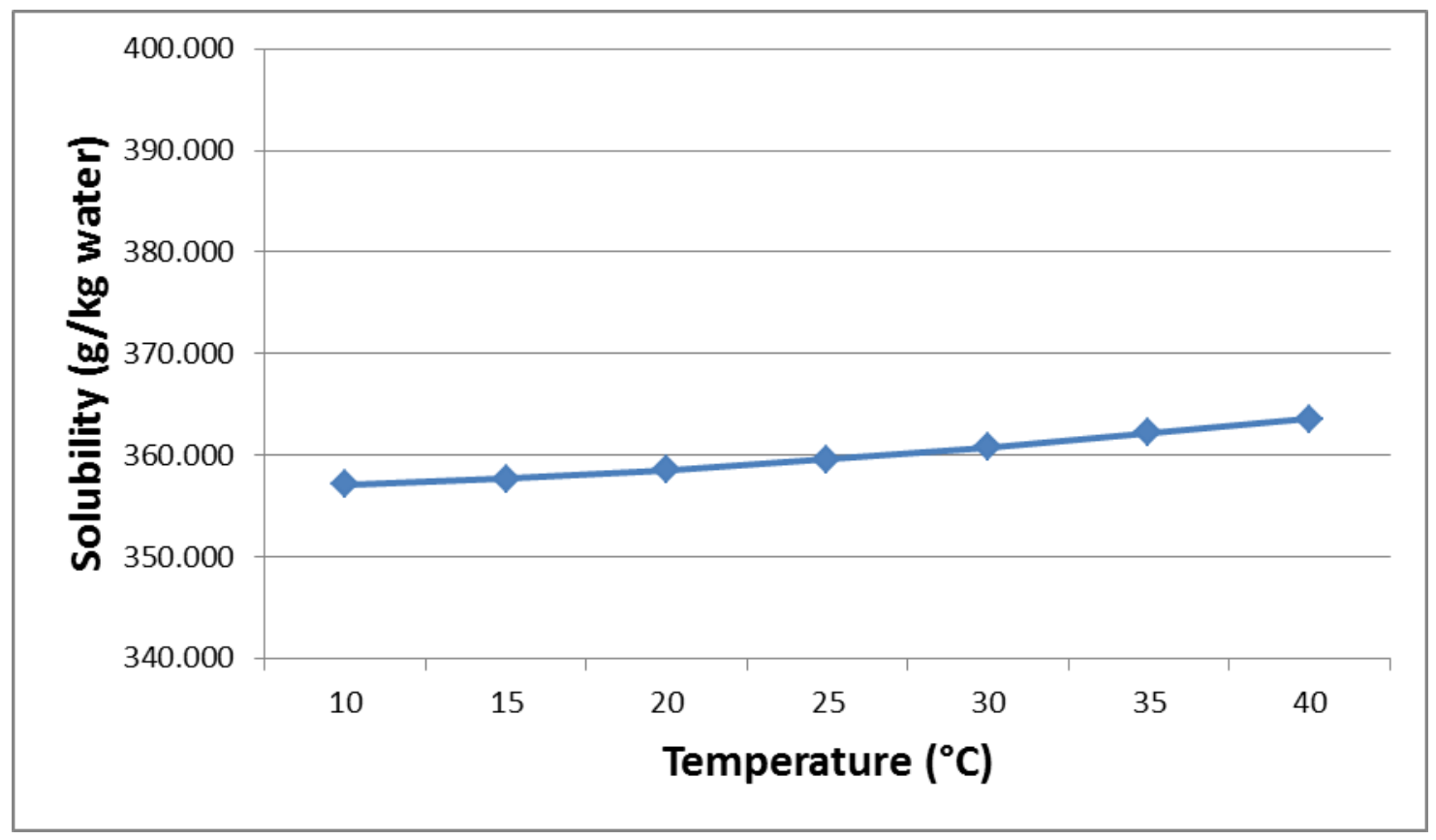

Figure 2. Solubility of sodium chloride at various temperatures. (Data from the CRC Handbook of Chemistry and Physics, 90th edition 2009-10, David Lide, ed., p. 830)

\section{Sodium Thiosulfate}

Sodium thiosulfate is typically used to deactivate chemical toxicants or therapeutants. According to available information, sodium thiosulfate would have some effectiveness toward most, but not all, of the taxa of concern. Most likely the toxic effects are due to the reaction and removal of oxygen from water. Toxicity data for the chemical indicate that it is not acutely toxic to aquatic organisms. It may present risk to non-target aquatic organisms at concentrations necessary to achieve rapid lethality. The material has low mammalian toxicity and, although the pure material can be irritating to eyes and skin, it is not likely to present a hazard to humans. Thiosulfate can cause rapid corrosion of metals under acidic conditions, but such conditions would not be expected in this application.

\section{Chlorine}

The available data indicate chlorine would be an effective option for treatment based on rapid lethality among the full range of taxa, although an outlier was found in the Pesticide Action Network (PAN) database with respect to chlorine toxicity to duckweed (4 day EC50 of $930 \mathrm{mg} / \mathrm{L}$ ), which indicates some aquatic plants are more tolerant than others (table 5). Chlorine, however, ranked poorly in the categories of impacts to lock structure, human safety, and likelihood of registration. It is highly corrosive and, in the presence of high organic content, can form a number of toxic compounds including chloramines, some of which are highly carcinogenic. Based on this use pattern, registration with the EPA could prove problematic. 


\section{Sodium Hydroxide}

Based on available data, sodium hydroxide would not be useful under the treatment scenario proposed. Using the most conservative estimates, it would take an enormous amount of sodium hydroxide to cause lethality in a short time. Goldfish are the only similar fish for which data are available. Using this as an example, it would take $160 \mathrm{mg} / \mathrm{L}$ to cause lethality in 24 hours (table 5). This number will, of course, be much higher to cause lethality in 30 minutes or less. As with sodium chloride, if we estimated a treatment volume of seven million gallons, that would require $4.24 \times 10^{9}$ milligrams or 9,337 pounds of sodium hydroxide. For contact times of 30 minutes or less, considerably more sodium hydroxide would be needed. Although sodium hydroxide is used in clearing sewer pipes and similar closed water systems, applications of that type facilitate long contact times. Furthermore, there are minimal issues with environmental release and human exposure in a closed-system treatment.

\section{Ultraviolet Light}

Ultraviolet light is limited in its capacity to penetrate water, even in clear water where effective penetration is limited to only a few centimeters (AAW, 2015). Turbid water is expected to have even lower penetration distance; furthermore, UV light will be useful only on smaller taxa and microorganisms. Large fish, crustaceans, and mollusks will not be affected by exposure. Consequently, UV light will not be useful in a scenario where rapid and broad-scope lethality are required.

\section{Control Method Effects on Taxonomic Groups}

Table 3 summarizes as much data as could be gathered on the effects of each control option on the taxa under consideration for the lock treatment control methods. Specific data are provided in table 5. Data are broken down into toxicity categories as indicated in the head note accompanying the table. LC50 less than $0.10 \mathrm{mg} / \mathrm{L}$ were considered very toxic and assigned a numerical rating of 5, while those exceeding $100 \mathrm{mg} / \mathrm{L}$ were considered not toxic and were assigned a numerical rating of 1 . Again, it is important to emphasize that the data expressed in this table are for contact times generally at a minimum of 24 hours. Contact times under 24 hours will require higher exposure concentrations; the ratings provided in table 2 are based on these considerations. 
Table 3. Toxicity of the various chemical treatment options to taxa of concern. Toxicity is ranked from 1 to 5 based on LC50 data where available.

[EPA, U.S. Environmental Protection Agency; ${ }^{\circ} \mathrm{C}$, degrees Celsius; MAK, Maximal Arbeitsstoff Konzentration (Maximal Material Concentration); NR, not reported by authors. Rating definitions: 1, Not acutely toxic LC50 greater than 100 milligrams per liter (mg/L); 2, slightly toxic LC50 10-100 mg/L; 3, moderately toxic LC50 1-10 mg/L; 4, highly toxic LC50 0.1-1 mg/L; and 5, very highly toxic LC50 less than $0.1 \mathrm{mg} / \mathrm{L}]$

\begin{tabular}{|c|c|c|c|c|c|c|c|c|c|}
\hline \multirow[b]{2}{*}{ Chemical } & \multirow[b]{2}{*}{ Mode of toxicity } & \multicolumn{7}{|c|}{ Toxicity rating category for taxa } & \multirow[b]{2}{*}{ Reference } \\
\hline & & $\begin{array}{c}\text { EPA } \\
\text { Registered }\end{array}$ & 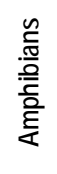 & 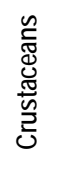 & $\frac{\bar{m}}{\frac{5}{4}}$ & $\frac{\text { ֻू }}{\text { wू }}$ & 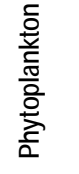 & 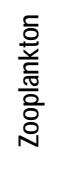 & \\
\hline Sodium chloride & Dehydrates tissues & Yes & 1 & 1 & 1 & 1 & 1 & 1 & PAN Database. \\
\hline Menadione & $\begin{array}{l}\text { Generates reactive oxygen } \\
\text { species; may inhibit } \\
\text { enzymes }\end{array}$ & No & NR & 3 & 4 & 3 & 3 & $3-4$ & $\begin{array}{l}\text { PAN Database; Andaya and } \\
\text { Di Guilio (1987); Wright } \\
\text { (2010). }\end{array}$ \\
\hline Ozone & $\begin{array}{l}\text { Forms free radicals that } \\
\text { damage tissues }\end{array}$ & Yes & 3 & $4^{++}$ & $3-4$ & 4 & 4 & $3^{\mathrm{b}}$ & $\begin{array}{l}\text { PAN Database, MAK Value } \\
\text { Documentation }(1998)^{* *} ; \\
\text { Honjo and others (2004); } \\
\text { Wright and others (2010) } \\
\text { Schroeder and others } \\
(2010)^{++} \text {. }\end{array}$ \\
\hline Hydrogen peroxide & $\begin{array}{l}\text { Causes corrosive damage, } \\
\text { forms oxygen gas that may } \\
\text { cause embolisms and } \\
\text { causes lipid peroxidation }\end{array}$ & Yes & 2 & 1 & 1 & 2 & 2 & 3 & $\begin{array}{l}\text { PAN Database; MAK Value } \\
\text { Documentation (2010). }\end{array}$ \\
\hline Sodium thiosulfate & $\begin{array}{l}\text { More of an irritant that an } \\
\text { toxic substance }\end{array}$ & No & NR & NR & 1 & NR & 2 & 1 & PAN Database. \\
\hline Chlorine & $\begin{array}{l}\text { Forms } \mathrm{HCl} \text { in aqueous } \\
\text { environments and highly } \\
\text { reactive atomic oxygen, } \\
\text { damages tissues }\end{array}$ & Yes & NR & 4 & $4-5$ & $3-5$ & $1-3$ & $4-5$ & $\begin{array}{l}\text { PAN Database; MAK Value } \\
\text { Documentation (2004). }\end{array}$ \\
\hline Sodium hydroxide & $\begin{array}{l}\text { Causes bonds in proteins to } \\
\text { break, severe necrosis }\end{array}$ & Yes & NR & 2 & 1 & 1 & NR & $1-2$ & $\begin{array}{l}\text { PAN Database; MAK Value } \\
\text { Documentation(1999). }\end{array}$ \\
\hline $43^{\circ} \mathrm{C}$ water & $\begin{array}{l}\text { Warmer water depletes O2, } \\
\text { suffocates organisms }\end{array}$ & & 5 & 5 & 5 & 5 & 5 & 5 & $\begin{array}{l}\text { Beyer and others (2011); } \\
\text { Moy (2007). }\end{array}$ \\
\hline
\end{tabular}




\section{Combinations of Control Methods}

Table 4 provides an assessment of the compatibility and potential utility of combinations of the various control methods if used in combination. As noted previously, these are based on limited data. Only binary combinations were considered. If a combination of treatments were judged to be incompatible, then it was assigned a value of 0 . If the combination was judged to have potential to be compatible and highly effective, it was given a value of 3 . The table indicates that hot water, in combination with other approaches, likely provides the best potential for control. Chemical incompatibility was the limiting factor in many of the combinations.

Table 4. Control method compatibility table. Each binary combination of control options was assessed for compatibility and given a score of 0 to 3 , with 0 being not compatible and 3 being compatible and likely to enhance toxicity.

$\left[{ }^{\circ} \mathrm{C}\right.$, degrees Celsius $]$

\begin{tabular}{|c|c|c|c|c|c|c|c|}
\hline & Ozone & Menadione & $\begin{array}{c}\text { Ultraviolet } \\
\text { light }\end{array}$ & $\begin{array}{l}\text { Sodium } \\
\text { thiosulfate }\end{array}$ & $\begin{array}{l}\text { Sodium } \\
\text { chloride }\end{array}$ & Chlorine & Sodium hydroxide \\
\hline $43^{\circ} \mathrm{C}$ water & 3 & 3 & 3 & 3 & 3 & 1 & 3 \\
\hline Ozone & & 0 & 0 & 0 & 3 & 0 & 2 \\
\hline Menadione & & & 0 & 2 & 3 & 0 & 0 \\
\hline UV & & & & 3 & 3 & 0 & 3 \\
\hline Sodium thiosulfate & & & & & 2 & 0 & 2 \\
\hline Sodium chloride & & & & & & 3 & 3 \\
\hline Chlorine & & & & & & & 0 \\
\hline Sodium hydroxide & & & & & & & \\
\hline
\end{tabular}


Table 5. Summary of toxicity data relevant to taxa of concern for lock-treatment control methods.

[EPA, U.S. Environmental Protection Agency; d, day; h, hour; min, minutes; g, gram; mm, millimeter; cm, centimeter; ${ }^{\circ} \mathrm{C}$, degrees Celsius; mg/L, milligrams per liter; NR, not reported by author; NOEL, no observed effect level; LOEC, lowest observed effect concentration; LC50, amount of pesticide in 1liter that is lethal to 50 percent of test organisms at stated test time; LD50, lethal dose to 50 percent of a population; EC50, the concentration of pesticide that produces the measurable effect in 50 percent of test organisms in stated test time; LETH, lethal concentration; g, grams; AI, active ingredient; PAN, Pesticide Action Network]

\begin{tabular}{|c|c|c|c|c|c|c|}
\hline Species & $\begin{array}{l}\text { Lifestage or } \\
\text { size }\end{array}$ & $\begin{array}{l}\text { Toxicity } \\
\text { endpoint }\end{array}$ & Mean concentration & $\begin{array}{l}\text { Physiological } \\
\text { response }\end{array}$ & $\begin{array}{c}\text { EPA } \\
\text { Registered }\end{array}$ & Reference \\
\hline \multicolumn{7}{|c|}{$43^{\circ} \mathrm{C}$ water } \\
\hline Mussel (D. polymorpha) & $10-35 \mathrm{~mm}$ & 5 min LC100 & $43^{\circ} \mathrm{C}$ & Mortality & \multirow[t]{3}{*}{ No } & \multirow{3}{*}{$\begin{array}{l}\text { Beyer and others, 2011, Acute upper } \\
\text { thermal limits of } 3 \text { aquatic invasive } \\
\text { invertebrates: hot water treatment to } \\
\text { prevent upstream transport of } \\
\text { invasive species: Environmental } \\
\text { Management, no. 47, p. 67-76. }\end{array}$} \\
\hline Mussel (D. r. bugensis) & 6-29 mm & 5 min LC100 & $43^{\circ} \mathrm{C}$ & Mortality & & \\
\hline $\begin{array}{l}\text { Spiny water flea } \\
\text { (B. longimanus) }\end{array}$ & NR & 5 min LC100 & $49^{\circ} \mathrm{C}$ & Mortality & & \\
\hline \multicolumn{7}{|c|}{ Ozone } \\
\hline Bluegill (L. macrochirus) & Eggs & 3 h LC50 & $0.39 \mathrm{mg} / \mathrm{L}$ & Mortality & \multirow[t]{6}{*}{ No } & \multirow[t]{5}{*}{$\begin{array}{l}\text { PAN Pesticide Database; } \\
\text { www.pesticideinfo.org. }\end{array}$} \\
\hline Bluegill (L. macrochirus) & Larvae & 0.3 h LC50 & $0.1 \mathrm{mg} / \mathrm{L}$ & Mortality & & \\
\hline $\begin{array}{l}\text { Channel catfish } \\
\text { (I. punctatus) }\end{array}$ & Larvae & 3 h LC50 & $0.47 \mathrm{mg} / \mathrm{L}$ & Mortality & & \\
\hline $\begin{array}{l}\text { Striped bass } \\
\quad \text { (M. saxatilis) }\end{array}$ & $13 \mathrm{~cm}$ & 6 h LC50 & $0.2 \mathrm{mg} / \mathrm{L}$ & Mortality & & \\
\hline $\begin{array}{r}\text { Rainbow trout } \\
\text { (O. mykiss) }\end{array}$ & 2-week larvae & 3 h LC50 & $0.19 \mathrm{mg} / \mathrm{L}$ & Mortality & & \\
\hline $\begin{array}{l}\text { Pacific white shrimp } \\
\text { (L. vannamei) }\end{array}$ & Juvenile & 24 h LC50 & $0.84 \mathrm{mg} / \mathrm{L}$ & & & Schroeder and others (2010). \\
\hline \multicolumn{7}{|c|}{ SeaKleen $\circledast$ (menadione) } \\
\hline $\begin{array}{l}\text { Channel catfish } \\
\text { (I. punctatus) }\end{array}$ & Yearling & 24 h LC50 & $1.2 \mathrm{mg} / \mathrm{L}$ & Mortality & \multirow[t]{4}{*}{ No } & \multirow[t]{4}{*}{$\begin{array}{l}\text { PAN Pesticide Database; } \\
\text { www.pesticideinfo.org. }\end{array}$} \\
\hline $\begin{array}{r}\text { Fathead minnow } \\
(P . \text { promelas })\end{array}$ & $26-34 d$ & NR & $0.11 \mathrm{mg} / \mathrm{L}$ & Mortality & & \\
\hline $\begin{array}{l}\text { Blue-green algae } \\
\text { (A. aeruginosa) }\end{array}$ & $\begin{array}{l}5 \mathrm{~d}(1-2)^{6} \\
\text { cells/mL }\end{array}$ & Lethal & 1 percent saturation & Mortality & & \\
\hline Daphnia magna & NR & 48 h LC50 & $0.4193 \mathrm{mg} / \mathrm{L}$ & Mortality & & \\
\hline \multicolumn{7}{|c|}{ Hydrogen peroxide } \\
\hline Clawed toad (X. laevis) & NR & 5 d LC50 & $20.366 \mathrm{mg} / \mathrm{L}$ & Mortality & \multirow[t]{6}{*}{ Yes } & \multirow[t]{6}{*}{$\begin{array}{l}\text { PAN Pesticide Database; } \\
\text { www.pesticideinfo.org. }\end{array}$} \\
\hline Clawed toad (X. laevis) & NR & $5 \mathrm{~d}$ NOEL & $12.516 \mathrm{mg} / \mathrm{L}$ & Mortality & & \\
\hline Coon-tail (C. demersum) & NR & $4 \mathrm{~d}$ LOEL & $34.0 \mathrm{mg} / \mathrm{L}$ & Mortality & & \\
\hline Coon-tail (C. demersum) & NR & $4 \mathrm{~d}$ NOEL & $34.0 \mathrm{mg} / \mathrm{L}$ & Growth & & \\
\hline $\begin{array}{l}\text { Red swamp crayfish } \\
\quad \text { (P. clarkia) }\end{array}$ & NR & 96 h ZERO & $64.619 \mathrm{mg} / \mathrm{L}$ & Mortality & & \\
\hline Walleye (S. vitreum) & Hatch & NR & $6.0 \mathrm{AI} \mathrm{mL} / \mathrm{L}$ & Mortality & & \\
\hline
\end{tabular}




\begin{tabular}{|c|c|c|c|c|c|c|}
\hline Species & $\begin{array}{l}\text { Lifestage or } \\
\quad \text { size }\end{array}$ & $\begin{array}{l}\text { Toxicity } \\
\text { endpoint }\end{array}$ & Mean concentration & $\begin{array}{l}\text { Physiological } \\
\text { response }\end{array}$ & $\begin{array}{c}\text { EPA } \\
\text { Registered }\end{array}$ & Reference \\
\hline $\begin{array}{l}\text { Channel catfish } \\
\text { (I. punctatus) }\end{array}$ & NR & 0.5 h LC50 & $5.0 \mathrm{AI} \mathrm{mL} / \mathrm{L}$ & Mortality & & \\
\hline $\begin{array}{l}\text { Channel catfish } \\
\text { (I. punctatus) }\end{array}$ & NR & 24 h LC50 & $0.555 \mathrm{AI} \mathrm{mL} / \mathrm{L}$ & Mortality & & \\
\hline Bluegill (L. macrochirus) & NR & 0.5 h LC50 & $2.01 \mathrm{AI} \mathrm{mL} / \mathrm{L}$ & Mortality & & \\
\hline $\begin{array}{r}\text { Rainbow trout } \\
\text { (O. mykiss) }\end{array}$ & $0.26 \mathrm{~g}$ fry & 0.5 h LC50 & $514 \mathrm{AI} \mathrm{mL} / \mathrm{L}$ & Mortality & & \\
\hline $\begin{array}{l}\text { Green algae } \\
\quad(D . \text { tertiolecta })\end{array}$ & NR & 5 min LOEL & $100 \mathrm{mg} / \mathrm{L}$ & Mortality & & \\
\hline Scud (Gammarus sp.) & NR & 96 h LD50 & $4.319 \mathrm{mg} / \mathrm{L}$ & Mortality & & \\
\hline Scud (Gammarus sp.) & NR & 24 h LETH & $6.802 \mathrm{mg} / \mathrm{L}$ & Mortality & & \\
\hline \multicolumn{7}{|c|}{ Sodium chloride } \\
\hline Frog (M. omata) & $8 \mathrm{~d}$, stage 24 & 96 h LC50 & 0.50 percent & Mortality & \multirow[t]{12}{*}{ Yes } & \multirow[t]{12}{*}{$\begin{array}{r}\text { PAN Pesticide Database; } \\
\text { www.pesticideinfo.org }\end{array}$} \\
\hline $\begin{array}{l}\text { Pondweed } \\
\text { (P.perfoliatus) }\end{array}$ & NR & 8 wk LOEL & $409.08 \mathrm{mg} / \mathrm{L}$ & Growth & & \\
\hline $\begin{array}{l}\text { Aquatic sowbug } \\
\quad(\text { A. communis })\end{array}$ & NR & 24 h LC50 & $5,600 \mathrm{mg} / \mathrm{L}$ & Mortality & & \\
\hline Goldfish (C. auratus) & $1.92 \mathrm{~g}$ & 24 h LC50 & $8,350 \mathrm{mg} / \mathrm{L}$ & Mortality & & \\
\hline Grass carp (C. idella) & Early fry & 0.5 h LC50 & $22,700 \mathrm{mg} / \mathrm{L}$ & Mortality & & \\
\hline Carp (C. carpio) & 17-19 d larvae & 15 min LC50 & $22,200 \mathrm{mg} / \mathrm{L}$ & Mortality & & \\
\hline $\begin{array}{r}\text { Flatly coiled gyraulus } \\
\text { (G. circumstriatus) }\end{array}$ & NR & 24 h LC50 & $10,000 \mathrm{mg} / \mathrm{L}$ & Mortality & & \\
\hline Pond snail (Lymnaea sp.) & Egg & 24 h LC50 & $3,412 \mathrm{mg} / \mathrm{L}$ & Mortality & & \\
\hline Diatom (N. linearis) & NR & 5d LC50 & $2,430 \mathrm{mg} / \mathrm{L}$ & Mortality & & \\
\hline $\begin{array}{l}\text { Blue-green algae } \\
\text { (A. doliolum) }\end{array}$ & NR & $12 \mathrm{~d}$ IC50 & $2,045 \mathrm{mg} / \mathrm{L}$ & $\begin{array}{l}\text { Population } \\
\text { growth rate }\end{array}$ & & \\
\hline Daphnia magna & NR & 24 h LC50 & $3,412 \mathrm{mg} / \mathrm{L}$ & Mortality & & \\
\hline $\begin{array}{l}\text { Scud } \\
\quad \text { (G. pseudolimnaeus) }\end{array}$ & NR & $\begin{array}{c}96 \mathrm{~h} \mathrm{NR}- \\
\text { Zero }\end{array}$ & $1,000 \mathrm{mg} / \mathrm{L}$ & Mortality & & \\
\hline \multicolumn{7}{|c|}{ Sodium thiosulfate } \\
\hline $\begin{array}{l}\text { Western mosquitofish } \\
\text { (G. affinis) }\end{array}$ & Adult female & 24 h LC50 & $26,400 \mathrm{mg} / \mathrm{L}$ & Mortality & \multirow[t]{5}{*}{ No } & \multirow[t]{5}{*}{$\begin{array}{l}\text { PAN Pesticide Database; } \\
\text { www.pesticideinfo.org }\end{array}$} \\
\hline $\begin{array}{l}\text { Fathead minnow } \\
\text { (P. promelas) }\end{array}$ & $0.3-0.6 \mathrm{~g}$ & 96 h LC50 & $10,000 \mathrm{mg} / \mathrm{L}$ & Mortality & & \\
\hline Diatom ( $N$. closterium) & NR & $48 \mathrm{~h}$ NOEC & $720 \mathrm{mg} / \mathrm{L}$ & $\begin{array}{l}\text { Population } \\
\text { abundance }\end{array}$ & & \\
\hline Daphnia magna & NR & 25 h LC50 & $2,245 \mathrm{mg} / \mathrm{L}$ & Mortality & & \\
\hline Protozoa (S. ambiguum) & NR & 24 h LC50 & $1,710 \mathrm{mg} / \mathrm{L}$ & Mortality & & \\
\hline
\end{tabular}




\begin{tabular}{|c|c|c|c|c|c|c|}
\hline Species & $\begin{array}{l}\text { Lifestage or } \\
\text { size }\end{array}$ & $\begin{array}{l}\text { Toxicity } \\
\text { endpoint }\end{array}$ & Mean concentration & $\begin{array}{l}\text { Physiological } \\
\text { response }\end{array}$ & $\begin{array}{c}\text { EPA } \\
\text { Registered }\end{array}$ & Reference \\
\hline \multicolumn{7}{|c|}{ Chlorine } \\
\hline $\begin{array}{l}\text { Duckweed } \\
\quad \text { (Lemna minor) }\end{array}$ & 20 colonies & 4 d EC50 & $930 \mathrm{mg} / \mathrm{L}$ & Growth & \multirow[t]{13}{*}{ Yes } & \multirow[t]{13}{*}{$\begin{array}{l}\text { PAN Pesticide Database; } \\
\text { www.pesticideinfo.org }\end{array}$} \\
\hline $\begin{array}{l}\text { Eurasian watermilfoil } \\
\quad(\text { M. spicatum })\end{array}$ & $\begin{array}{c}5 \mathrm{~cm} \text { shoot } \\
\text { length }\end{array}$ & $2 \mathrm{~h}$ & $0.53 \mathrm{mg} / \mathrm{L}$ & Growth & & \\
\hline $\begin{array}{l}\text { Aquatic sowbug } \\
\text { (A. aquaticus) }\end{array}$ & $\begin{array}{c}\text { Mature, non- } \\
\text { reproducing }\end{array}$ & 24 h LC50 & $0.315 \mathrm{mg} / \mathrm{L}$ & Mortality & & \\
\hline $\begin{array}{l}\text { Aquatic sowbug } \\
\text { (A. racovitzai) }\end{array}$ & NR & 0.5 d LC50 & $1.46 \mathrm{mg} / \mathrm{L}$ & Mortality & & \\
\hline Crayfish (O. rusticus) & NR & 96 h LETH & $1 \mathrm{mg} / \mathrm{L}$ & Mortality & & \\
\hline Brook trout (S. fontinalis) & $11-15 \mathrm{~cm}$ & 9 h LC100 & $0.35 \mathrm{mg} / \mathrm{L}$ & Mortality & & \\
\hline $\begin{array}{l}\text { Western mosquitofish } \\
\text { (G. affinis) }\end{array}$ & $2-3.5 \mathrm{~mm}$ & 0.5 h LC50 & $1.59 \mathrm{mg} / \mathrm{L}$ & Mortality & & \\
\hline $\begin{array}{l}\text { Blacknose dace } \\
\text { (R. atratulus) }\end{array}$ & $40.2 \mathrm{~mm}$ & 0.35 h LC50 & $6.6 \mathrm{mg} / \mathrm{L}$ & Mortality & & \\
\hline Snail (Anculosa sp) & NR & 24 h LC50 & $8.3 \mathrm{mg} / \mathrm{L}$ & Mortality & & \\
\hline $\begin{array}{l}\text { Green algae } \\
\quad \text { (S. acuminatus) }\end{array}$ & NR & $0.5 \mathrm{~h}$ & $7.5 \mathrm{mg} / \mathrm{L}$ & Mortality & & \\
\hline Daphnia magna & NR & 24 h LC50 & $0.076 \mathrm{mg} / \mathrm{L}$ & Mortality & & \\
\hline Daphnia magna & $2-3.5 \mathrm{~mm}$ & 0.5 h LC50 & $0.079 \mathrm{mg} / \mathrm{L}$ & Mortality & & \\
\hline Scud (G. minus) & NR & 0.33 d LC50 & $0.0764 \mathrm{mg} / \mathrm{L}$ & Mortality & & \\
\hline \multicolumn{7}{|c|}{ Sodium hydroxide } \\
\hline Goldfish (C. auratus) & NR & 24 h LC50 & $160 \mathrm{mg} / \mathrm{L}$ & Mortality & \multirow[t]{4}{*}{ Yes } & \multirow[t]{4}{*}{$\begin{array}{l}\text { PAN Pesticide Database; } \\
\text { www.pesticideinfo.org }\end{array}$} \\
\hline $\begin{array}{l}\text { Western mosquitofish } \\
\text { (G. affinis) }\end{array}$ & Adult female & 24 h LC50 & $125 \mathrm{mg} / \mathrm{L}$ & Mortality & & \\
\hline Pond snail (Lymnaea sp) & NR & 24 h LETH & $150 \mathrm{mg} / \mathrm{L}$ & Mortality & & \\
\hline Daphnia magna & NR & $48 \mathrm{~h}$ & $100 \mathrm{mg} / \mathrm{L}$ & Mortality & & \\
\hline
\end{tabular}

Steps in creating table:

1. Searched PAN database for specific chemical

2. Focused on the ecotoxicity link in the database

3. Assessed the various biological classes and selected the shortest lethal time and its corresponding concentration 


\section{Potential Control of Scud (Gammarus spp.)}

A brief summary on control of scud is included because there is special concern for certain invasive species. There is limited information on the toxicity of pesticides and herbicides to scuds. In a brief review of the literature, very limited information was found for effects of potential lock treatment chemicals on scuds. For example, the $24 \mathrm{~h} \mathrm{LC50}$ for field grade 3-trifluoro-4-nitrophenol (TFM) in the mature scud (Gammarus pseudolimnaeus) is $100 \mathrm{mg} / \mathrm{L}$ (Sanders and Walsh, 1975). Scuds (Gammarus lacustris) were susceptible to rotenone but the $24 \mathrm{~h} \mathrm{LC50}$ was at $6,000 \mathrm{mg} / \mathrm{L}$. Similarly, they were susceptible to 2,4-D but the $24 \mathrm{~h}$ LC50 was 2,100 mg/L. Mature Gammarus pseduolimnaeus had a $48 \mathrm{~h}$ LC50 of $43 \mathrm{mg} / \mathrm{L}$ to glyphosate (Folmar and others, 1979). In another study, scuds were more susceptible to organophosphate pesticides (Sanders, 1969) but human health concerns likely would eliminate these as potential lock treatment options. However, the invasive scud Echinogammarus ischnus is susceptible to hot water. It can tolerate a maximum water temperature ranging from 31.0 to $32.2^{\circ} \mathrm{C}$ before irreversible physiological damage and mortality occur (Wijnhoven and others, 2003).

\section{Registration of Control Methods}

It is important to understand that all of these approaches would require regulatory approval. Section 2(u) of FIFRA defines a "pesticide" as "any substance or mixture of substances intended for preventing, destroying, repelling, or mitigating any pest." The fact that a substance is already registered does not preclude the requirement for registration for this type of use. The registration of a pesticide is based on a specific use pattern. Using it in any other manner, unless that manner has been evaluated and approved by the EPA, is prohibited. In the circumstance of a lock treatment, the mode of application, duration, and frequency are all different than typical applications. Consequently, although traditional aquatic pesticides were considered in this evaluation, development of these chemicals for use in a locktreatment scenario is not consistent with typical application patterns. These chemicals were not developed and registered for this type of use pattern. These chemicals are intended to deliver lethal doses over longer time periods (6 to 9 hours or longer). Use in a lock-treatment scenario would require significantly higher doses to be effective in short time periods. Although recycling could be used to minimize the volume of water treated, significant quantities of a chemical would be needed. Seepage from the lock during treatment would have to be addressed as this would lead to environmental and human exposures. Unless the treatment process can be engineered in such a way that environmental and human exposure would be prevented, registering these chemicals for this type of use may present a significant challenge.

\section{Summary}

Based on the results obtained in this assessment, the most effective approach for treating vessels moving through the locks is to use water at an elevated temperature $\left(43-49^{\circ} \mathrm{C}\right)$. It has provided the best combination of efficacy to the taxa of concern, cost, human and environmental safety, safety to vessels or the lock structure, and potential for registration for this purpose.

Combinations of treatment approaches may enhance control of aquatic invasive organisms during lock operations. For example, combinations of hot water with a chemical or physical method to enhance control may be an alternative approach. Menadione and chlorine both show toxicity toward a wide range of taxa. More testing is necessary to establish the concentrations required to produce lethality under short contact times and to determine how the materials could be applied in an approach channel or lock structure. 


\section{References}

American Air and Water (AAW), 2015, Types of UV light-UV C, UV B, UV A: accessed February 4, 2015, at http://www.americanairandwater.com/uv-facts/uv-types.htm.

Andaya, A.A., and Di Giulio, R.T., 1987, Acute toxicities and hematological effects of two substituted naphthoquiones in channel catfish: Archives of Environmental Contamination and Toxicology, v. 16, no. 2, p. 233-238.

Beyer, Jessica, Moy, Philip, and De Stasio, Bart, 2011, Acute upper thermal limits of three aquatic invasive invertebrates: Hot water treatment to prevent upstream transport of invasive species:

Environmental Management, v. 47, no. 1, p. 67-76.

Lide, David, (ed.), 2009, CRC Handbook of chemistry and physics (90th ed.): Boca Raton, Florida, CRC Press, p. 830.

Dawson, V.K., and Kolar, C.S. (eds.), 2003, Integrated management techniques to control nonnative fishes: U.S. Geological Survey, Upper Midwest Environmental Sciences Center, 146 p., plus 6 app.

Folmar, L.C., Sanders, H.O., and Julin, A.M., 1979, Toxicity of the herbicide glyphosate and several of its formulations to fish and aquatic invertebrates: Archives of Environmental Contamination and Toxicology: v. 8, no. 3, p. 269-278.

Federal Insecticide, Fungicide, and Rodenticide Act (FIFRA), 1947 and revisions (Title 7, U.S. Code, sections 136-136y).

Great Lakes Mississippi River Interbasin Study (GLMRIS) Team, 2012, Inventory of available controls for aquatic nuisance species of concern-Chicago Area Waterway System: U.S. Army Corps of Engineers, Chicago District, 17 p., 3 app., accessed Apr. 1, 2015, at http://glmris.anl.gov/documents/docs/ANS_Control_Paper.pdf.

Honjo, Tsuneo, Imada, Noboyoshi, Anraku, Yasuhiro, Kim, Dae-ll, Muramatsu, Mikiko, and Oshima, Yuji, 2004, Removal of harmful red tide plankton by ozone treatment, in Steidinger K.A., Landsberg, J.H., Tomas, C.R., and Vargo, G.A. (eds.), Harmful algae 2002: St. Petersburg, Florida Fish and Wildlife Commission, Florida Institute of Oceanography, and Intergovernmental Oceanographic Commission of UNESCO, p. 525-527.

The MAK Collection for Occupational Health and Safety, 2015: John Wiley and Sons, Inc., accessed March 25, 2015, at http://onlinelibrary.wiley.com/book/10.1002/3527600418.

Marking L.L., 1970, Juglone (5-hydroxy-1,4,-naphthoquinone) as a fish toxicant: Transactions of the American Fisheries Society, v. 99, no. 3, p. 510-514.

Moy, P.B., 2007, AIS control and monitoring plan for the Rapide Croche boat transfer station: accessed December 3, 2104, at http://www.friendsofthefox.org/projects/rapid-croche-boat-transfer/.

Moy, P.B., Polls, Irwin, and Dettmers, J.M., 2011, The Chicago Sanitary and Ship Canal aquatic nuisance species dispersal barrier, in Chapman, D.C, and Hoff, M.H., Invasive Asian carps of North America: Bethesda, Maryland, American Fisheries Society Symposium 74, p.121-137.

Pesticide Action Network (PAN) Pesticide Database, 2014, accessed Dec. 2, 2014, at http://www.pesticideinfo.org/.

Sanders, H.O., 1969, Toxicity of pesticides to the crustacean Gammarus lucustris: Technical Papers of the Bureau of Sport Fisheries and Wildlife, U.S. Department of the Interior, Fish and Wildlife Service, $18 \mathrm{p}$.

Sanders, H.O., and Walsh, D.F., 1975, Toxicity and residue dynamics of the lampricide 3trifluoromethyl-4-nitrophenol (TFM) in aquatic invertebrates: U.S. Department of the Interior, Fish and Wildlife Service, Investigations in Fish Control, no. 59, 9 p. 
Schroeder, J.P., Gartner, Andrea, Waller, Uwe, and Hanel, Reinhold, 2010, The toxicity of ozoneproduced oxidants to the Pacific white shrimp Litopenaeus vannamei: Aquaculture, v. 305, no. 1-4, p. 6-11.

Wijnhoven, Sander, van Riel, M.C., and van der Velde, Gerard, 2003, Exotic and indigenous freshwater gammarid species: physiological tolerance to water temperature in relation to ionic content of the water: Aquatic Ecology, v. 37, no. 2, p. 151-158.

Wright, D.A., Dawson, Rodger, and Orano-Dawson, C.E., 2007, Shipboard trials of menadione as a ballast water treatment: Marine Technology, v. 40, no. 1, p. 68-76.

Wright, D.A., Dawson, Rodger, Caceres, Vanessa, Orano-Dawson, C.E., Kananen, G.E., Cutler, S.J., and Cutler, H.G., 2009, Shipboard testing of the efficacy of SeaKleen ${ }^{\circledR}$ as a ballast water treatment to eliminate non-indigenous species aboard a working tanker in the Pacific waters: Environmental Technology, v. 30, no. 9, p. 893-910.

Wright, D.A., Gensemer, R.W., Mitchelmore, C.L., Stubblefield, W.A., van Genderen, Eric, Dawson, Rodger, Orano-Dawson, C.E., Bearr, J.S., Mueller, R.A., and Cooper, W.J., 2010, Shipboard trials of an ozone-based ballast water treatment system: Marine Pollution Bulletin, v. 60, p. 1571-1583. 

